\title{
Impact of Turbocharger Compressor Pressure Ratio on Diesel Engine Performance and Nitrogen Oxides Emissions
}

\author{
Abdullah Alghafis", Eihab A Raouf, Abdumalik Aldahlawi, Faisal Alassaf, Abdulmajeed Alrsheedi, \\ Amer Alharbi
}

Department of Mechanical Engineering, Unaizah Engineering College, Qassim University, Saudi Arabia

Received April 11, 2020; Revised May 7, 2020; Accepted May 29, 2020

Copyright $\bigcirc 2020$ by authors, all rights reserved. Authors agree that this article remains permanently open access under the terms of the Creative Commons Attribution License 4.0 International License

\begin{abstract}
Turbochargers is used on several engines since 1962, to gain greater power output. This paper presents a study of the impact of the turbocharger pressure ratio on diesel engine performance and nitrogen oxides $\left(\mathrm{NO}_{\mathrm{X}}\right)$ emissions. A series of simulation experiments were carried out by using Diesel-RK software on variable turbocharger pressure ratio diesel engine. Diesel-RK is known as a very good open source software for youthful researchers, since it is free and talented of simulating combustion and thermodynamics of diesel engines very well. The simulated results showed that, turbocharger pressure ratio $(\mathrm{PR})$ is an important parameter which affects directly on engine performance, engine brake power (BP) increased when pressure ratio increased. At 2500rpm and pressure ratio equal to 1.5 the $\mathrm{BP}$ increment about $27.4 \%$ when compared to natural aspirated (NA) engine. More increment about $55 \%$ is achieved by increasing the pressure ratio to 2.5. Though the specific fuel consumption (SFC) reduced as the pressure ratio increased. At 4000rpm and pressure ratio equal to 1.5 the SFC reduction about $5 \%$ when compared to NA engine. More decrement rate in the SFC rate about $7 \%$ is achieved by increasing the turbocharger pressure ratio to 2.5 . The brake thermal efficiency (BTE) also increased as the pressure ratio increased, due to increase in power. At NA engine and $3000 \mathrm{rpm}$, the BTE is found to be $32.5 \%$, while at $\mathrm{PR}=1.5$, the BTE is equal to $33.9 \%$ and the BTE at the PR equal to 2.5 is increased to $33.8 \%$. On the other hand engine NOx emissions increased as the pressure ratio increased, at $3000 \mathrm{rpm}$ and PR equal to 1.5 , the $\mathrm{NO}_{\mathrm{X}}$ rate increased at a rate of $20 \%$ when compared to the emissions of NA engine. $\mathrm{NO}_{\mathrm{X}}$ emissions continuously increased and reached more than $42 \%$ with PR equal to 2.5 when compared to NA engine. Turbocharger gives the small displacement engines much more power relative to their size e.g. PR equal to 2.5 ,
\end{abstract}

turbochargers run off energy of exhaust gases that is always lost by the NA engines, so the recovery of this energy develops the engine efficiency.

Keywords Compressor Pressure Ratio, Engine Performance, Nitrogen Oxides Emissions, Energy, Diesel Engine

\section{Introduction}

Combustion, simply is a chemical process in which the thermal energy released when burning the air fuel mixture. There are two types of engines, internal and external combustion engine, the distinct of the internal combustion engine are that fuel ignition and piston expansion occurs inside the engine. There is a partial conversion of the energy from chemical energy to useful output power. Most of the engines today are four-stroke engines (to complete one cycle needs four piston strokes), the four strokes are intake, compression, power stroke, and exhaust. internal combustion engines (ICE) can divide into two categories spark ignition engine use gasoline fuel and the compression ignition engine use diesel fuel.

In a diesel engine, only the air is induced into the cylinder through the intake valve and then compressed by the piston. Then diesel fuel at a suitable time and measured rate injects into the high temperature compressed air, causing the fuel to burn. During the last 40 years, the research helps the ICE manufacturers to develop and improve the engine performance and reduce the exhaust emissions, researches work concentrated on creating internal combustion engines much efficient with least emissions. The internal combustion engine is the very 
essential in our community, it uses extending from marine propulsion to generating electric power.

Engine power differs significantly, mainly on the number of cylinders, engine arrangement, and turbocharging. Increasing the output power isn't merely on increase the number of cylinders or increase engine displacement; actually great performance four stroke engines can readily equal or override the power six engine cylinder.

\section{Literature Review}

In an engine, the energy in the fuel (chemical energy) is transformed to thermal energy during the combustion, the heat drives to expand the piston downwards and tends to rotate the crankshaft. The intake stroke (first stroke) initiated when the air come into the combustion chamber while the intake valves are kept open. At the compression stroke $\left(2^{\text {nd }}\right.$ stroke), the air drawn inside the cylinder is compressed when the piston travels upwards from bottom dead center (BDC) to top dead center (TDC) while the intake valves are closed. The charged air is then after compression occupying smallest volume as the piston approaches the TDC. At this point, the fuel is injected into the compressed air and leads to an ignition of fuel for a short time. Too much amount of compressed air drives more combustion of diesel in the combustion chamber. Thus, more output power is obtainable to drives the engine crankshaft. [1]

Diesel engine is a type of internally combusted engine. The strokes of the diesel engine are similar as in the gasoline engine, the main difference between these two type of engines is the fuel burning method. The gasoline engines utilize spark to begin the fuel burning, while the diesel engines press the air then injects the diesel fuel into the combustion chamber, the piston presses the fresh air inside cylinder, increasing the temperature of the air. The diesel is then sprayed in the combustion chamber into the hot air, this process tends to hot air to ignites the fuel immediately. The burning products (gases) extend and forces the piston downwards, and creates an output power. The power produces from the movement of the piston downward is acted to rotate the crankshaft. The fourth stroke is the exhaust stroke, which the piston moves upwards after expansion liberates the hot gases out the engine. [2]

To boost the engine output power, the pushing force in the cylinder have to be raised. Many methods are used to growth the engine power. The more widespread method uses to rise the output power is to increase the amount of fresh air in the cylinder by boost the air density. A turbochargers use the unused energy in the exhaust gases to rotate the compressor and press the air entering the cylinder, thus growing the engine power. Some of the unused heat energy in the exhaust gas can be regained by a turbocharger and transformed to useful work. [3]

Turbocharger delivers more air into the combustion chambers which, in turn, more power and torque are created when the piston is expanded downward by the resulting explosion from combustion. This charge is accomplished by compressing the air, so that the air is denser when drawn. Turbocharger is an air compressor, that air pressure is increased in the engine by taking air from atmosphere. [4]

Fig. 1 shows the turbine wheel is linked by a shaft to rotate the compressor wheel. As the turbine wheel turns speedy, it causes the compressor wheel to rotate quickly. The rotation of the compressor wheel sucks in the fresh air and compresses it before driving it into the combustion chambers. The power required to rotate the compressor is generating from exhaust gases kinetic energy. [5]

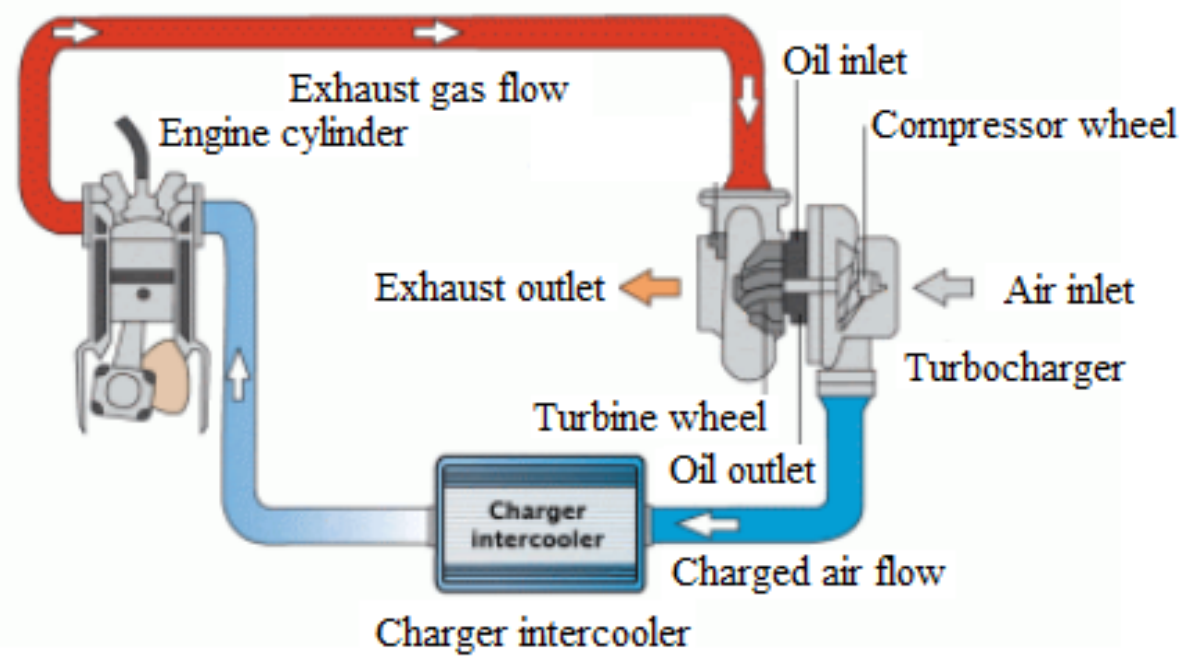

Figure 1. Turbocharged engine 
Thus, the compressed air should have passed through heat exchangers (intercooler) before derived into the cylinder, thus the air leaving the compressor extremely hot and less dense because of the compression, the intercooler is used to reduce the temperature of the as it enters the chambers [6]. In natural aspirated engines, intake air derived into the cylinder as a result of vacuum pressure caused by the piston downward movement, which allows the atmospheric air to drawn inside the cylinder. The ratio between the air volume actually drawn to theoretic volume (cylinder cross section area $\times$ stroke), is known as volumetric efficiency. The turbocharger is use to rise the engine volumetric efficiency, and the effect, is a more inflowing air for every suction stroke [7]. The effect of turbocharger pressure ratio on diesel engine, where the output power is improving without increasing the engine bulk, the engine improving along with the development of the air charging and the system of fuel injection. Turbochargers are used mainly on Diesel engines with waste-gated type. Lately, the turbocharger with variable geometry (VGT) with adaptable jet blades is progressively used, particularly for a passenger car [8].

Exhaust gas contains nitrogen oxides, carbon monoxide (CO), unburned hydrocarbons (UHCs) and smoke emissions. These emissions have been adjusted by regulations in many countries. One of the major problem which faced by the engine manufacturers is to reduce and minimize the emissions of the diesel engine without a serious modifications of engine. The greenhouse gases are influenced by the burning of fossil fuels. This leading to the air pollutions. Climate change exists as a result of existence of engine exhaust gases in the air. Carbon Dioxide is estimated as the major source for global warming. Exhaust emissions from vehicles are the source of ecological pollution and help to change the features of climate. [9]

Internal combustion engines $\mathrm{NO}_{\mathrm{X}}$ emissions rated more than $50 \%$ of total emissions. The second highest and important emissions from diesel engines is the particulate matter (PM). Carbon monoxide and Hydrocarbons are emitted as a result of air-fuel ratio that includes less charged air than the stoichiometric ratio and are lower existence. furthermore, engine emissions contain a low amount of sulphur dioxide $\left(\mathrm{SO}_{2}\right)$ subjecting to the quality of Sulphur in fuel. There are no techniques to handling and reduce $\mathrm{SO}_{2}$ emissions [10]. $\mathrm{NO}_{\mathrm{X}}$ is a nuisance gas and at high rates causes infections of the respiratory system. Nitrogen oxides is created mainly of nitric oxide (NO) and a smaller percentage of nitrogen dioxide $\left(\mathrm{NO}_{2}\right)$. When atmospheric nitrogen gas is unchained through fuel burning it integrates with excess atoms of oxygen to produce nitric oxide. Further, NO reacts with oxygen atoms to produce nitrogen dioxide. NO is not looked to be risky to health at low concentrations level, however $\mathrm{NO}_{2}$ can be. Both nitrogen dioxide and nitric oxide are denoted as oxides of nitrogen or nitrogen oxides. NOx gases interact to form acid rain and smog, also being significant factor to creates the fine Particles Matter and ground level ozone, together are linked with opposite human health effects. In areas of much vehicles traffic, like large towns and cities, the total emissions of nitrogen oxides released into the atmosphere is considered to be significant. Nitrogen oxides are created wherever combustion take place. $\mathrm{NO}_{\mathrm{X}}$ mainly impacts on respiratory conditions. Exposure for a longer time will drop the lung function, the hazard of respiratory conditions can increase and also increases the response to allergens. [11]

Diesel engines are looked as the highest providers of $\mathrm{NO}_{\mathrm{X}}$ emissions. Diesel engine requests higher compressed air temperatures for combust the diesel fuel. Acid rains and smog formulation are produced by the emissions of $\mathrm{NO}_{\mathrm{X}}$. Tropospheric ozone essentially created in the air from the emissions of $\mathrm{NO}_{\mathrm{X}}$ reacts chemically with other contaminants. Both nitrogen dioxide and nitric oxide are poisonous; but the level of poisonousness of Nitrogen Dioxide is five times more than the level of nitric oxide. [12]

\subsection{Problem Statements}

In diesel engine, the intake air is mainly compulsory by the turbocharger to keep great intake air pressure to gain more power from the ignition process. The engine brake power, brake thermal efficiency, specific fuel consumption and nitrogen oxides emissions are affected by the amount and pressure of intake air.

\subsection{Objectives}

The objectives of this study is to investigate the influence of different turbocharger pressure ratios on the diesel engine performance brake power, brake specific fuel consumption, brake thermal efficiency and Nitrogen Oxides emissions when compared with natural aspirated engine.

\section{Methodology and Materials}

A simulation software Diesel-RK is used to simulate the turbocharged diesel engine, Diesel - RK is a Russian project. Since 1981 the software was improved as a tool for simulation and optimization of internal combustion engines with different engine parameters. The improvement of the Diesel-RK software core has been at Bauman Moscow State Technical University (MSTU) the department of Internal Combustion Engines (Piston Engines), therefore, a particular significance was made on the suitability of the mathematical models and algorithms. During years, the effort has been continuously achieved in touch with IC engines engineers and computational researchers referring to the order of different of Internal Combustion Engines manufacturers. The software strength 
has been examined to appropriate multi engines of different types and uses. Several computational processes and choices were introduced for the software to suit the request of industrial enterprises including largest engine manufacturers in Russia. DIESEL software improvement using always advanced mathematical models of combustion process in a diesel engine. Recently, the software meets the diesel injection characteristics and precision of fuel atomizing, development of fuel sprays dynamics. Accounting the emissions of $\mathrm{NO}$ is achieved by the Zeldovich mechanism. The diesel-RK contains visualization of the fuel spray code. This code permits the servant to analyze the animation picture of development the sprays of fuel, their interaction with combustion chamber. The code is helpful to design the shape of piston bowl and in producing a proper option of diameter, number of injector nozzles and directions for a specific fuel supply characteristic.

\subsection{Diesel Engine Specifications [13]}

- Engine type: 1VD-FTV

- Max. power: single turbocharger (brake $\mathrm{hp} / \mathrm{kW})=$ $202 / 151 \mathrm{~kW}$ at $3600 \mathrm{rpm}$

- Turbocharged diesel engine.

- Intercooler system.

- V - line engine design.

- 8 cylinders -32 valves.

- Cylinder bore $86 \mathrm{~mm}$.

- Stroke $96 \mathrm{~mm}$.

- Compression ratio 16.8

- Crankshaft radius to length of connecting rod length $=0.214$

- Liquid cooling.

- Ambient parameters:

- Pressure 1 bar.

- Temperature $313 \mathrm{~K}$.

- Overland application.

\subsection{Diesel Fuel Specifications}

- Composition mass fraction $(\mathrm{C}=0.87$ and $\mathrm{H}=0.13)$.

- Chemical composition of the fuel $\left(C_{15} H_{28}\right)$

- Sulfur fraction in fuel $=150 \mathrm{ppm}$.

- Fuel Calorific value $=43.45(\mathrm{MJ} / \mathrm{kg})$.

- Cetane number $=56.5$.

- Fuel Density at $323 \mathrm{~K}=930\left(\mathrm{~kg} / \mathrm{m}^{3}\right)$

- Surface tension factor of fuel at $323 \mathrm{~K}=0.031$ $(\mathrm{N} / \mathrm{m})$.

- Dynamic viscosity coefficient of fuel at $323 \mathrm{~K}=$ 0.035 (pa.s).

- $\quad$ Specific vaporization heat $=250(\mathrm{~kJ} / \mathrm{kg})$.

- Molecular mass of fuel $=208$.

\subsection{Research Approach}

The experiments were performed by using simulation software Diesel - RK. The operating conditions of the simulation are as follow: -

- At different engine speeds $(750,1000,1500,2000$, 2500, 3000, 4000 and 5000rpm).

- At different turbocharged pressure ratio (NA, 1.5, 2.5 and 4$)$.

\subsection{Preprocessor of Diesel - RK}

Diesel - RK software formulates a number of windows, these windows used for entry the data and all specifications and characteristics of the fuel and the engine. User just has to answer the questions in the windows

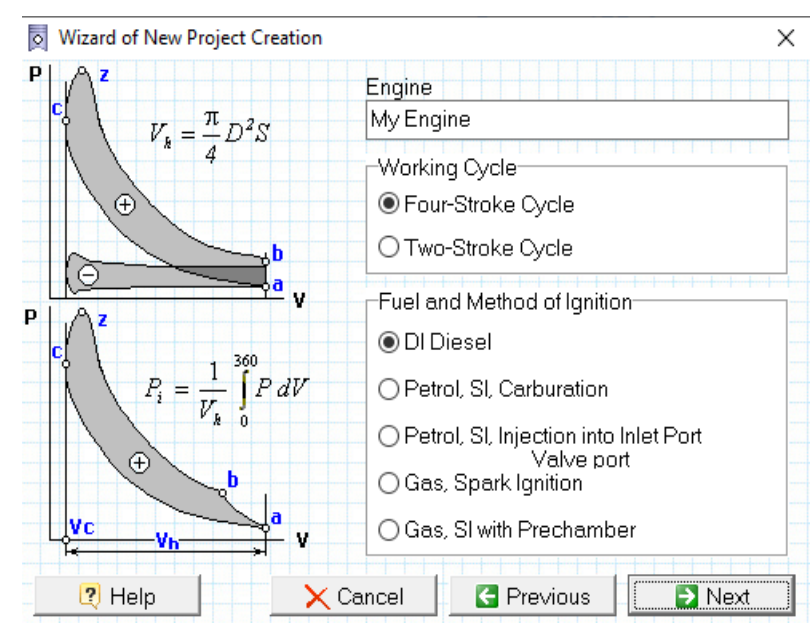

Figure 2. The selection of engine cycle, fuel and method of ignition

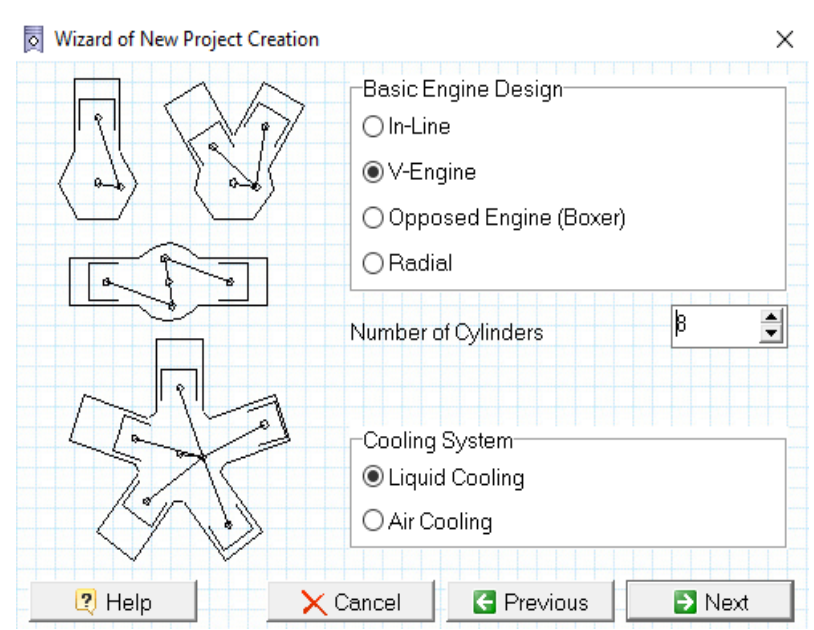

Figure 3. Selection the basic engine design, number of cylinders and type of cooling system 


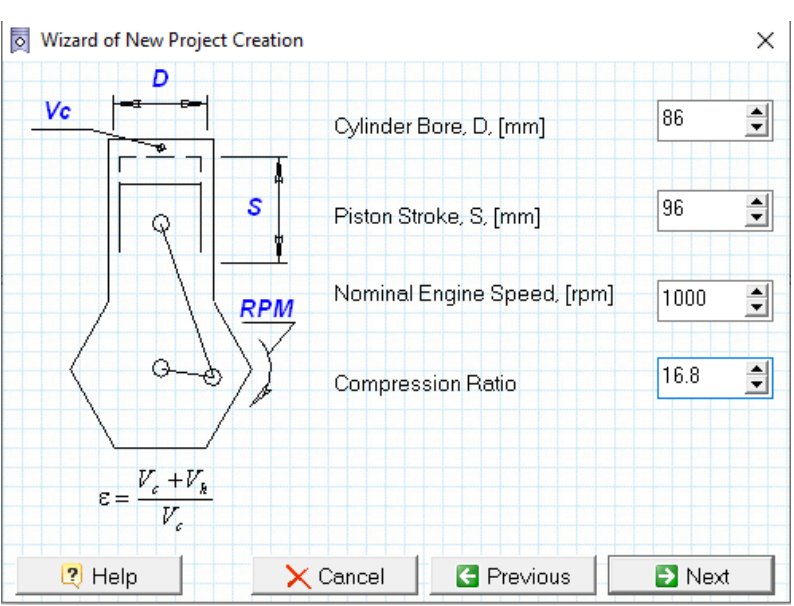

Figure 4. Engine geometrical dimensions cylinder bore, stroke, engine speed and compression ratio

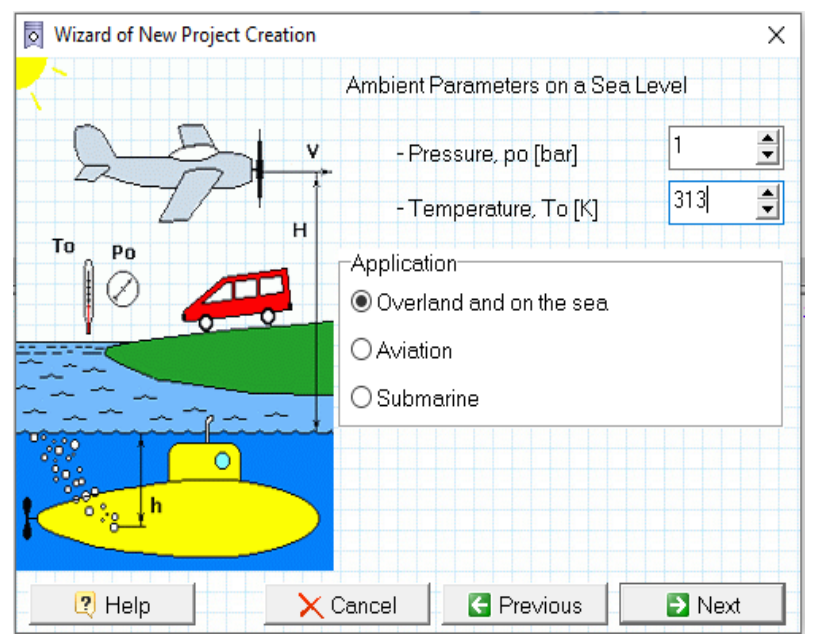

Figure 5. Options that selected of ambient parameters (pressure and temperature) and engine application

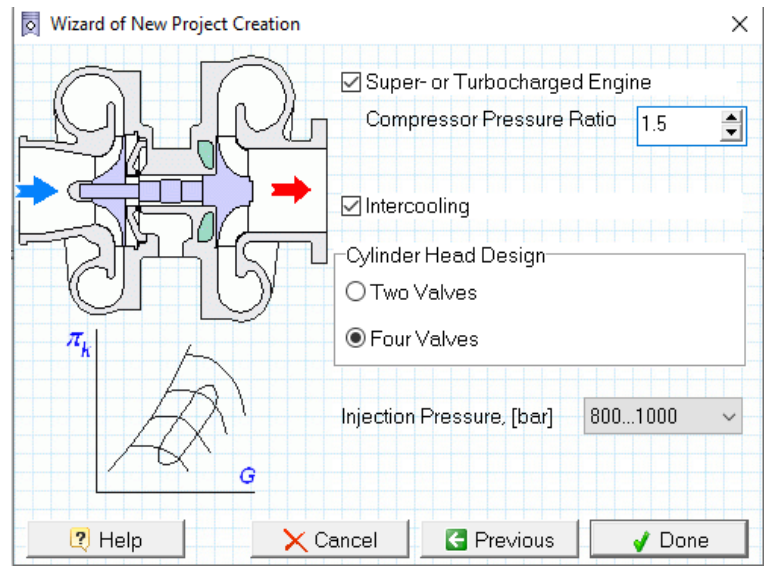

Figure 6. Options that selected for compressor pressure ratio and number of valves per each cylinder

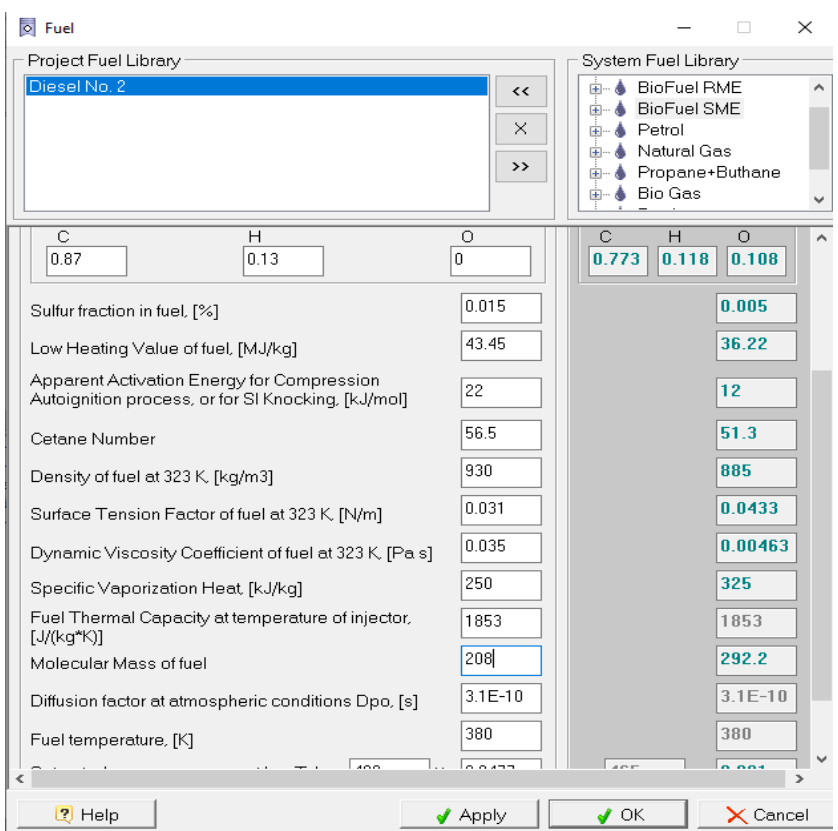

Figure 7. Fuel selection and fuel specifications

\section{Results and Discussions}

A brief discussion will be given for all results obtained from simulation software. The most interested parameters of the turbocharged diesel engine that will be discussed are the Brake Power (BP), Brake specific fuel consumption $(B s f c)$, and brake thermal efficiency (BTE). Brake power (BP) is the engine power measurement before losses caused by assisting components such as gearbox, alternator, water pump, and power steering pump. Brake power mentions to apparatus which is utilized to hold the engine at a required speed. Throughout the tests, the output power is calculated by measuring the engine torque and rotational speed.

The $B s f c$ is the ratio between the fuel consumption per unit time and the brake power, and acts as a very useful parameter, especially when engines performance is compared at different operating conditions. It is the rate of fuel consumption divided by the power produced.

The BTE will be used to calculate the power ratio, the ratio between the input power in the form of brake power and chemical energy in the fuel. This property will indicate how much the fuel power will be converted to a useful power.

Table 1 shows the data of the engine performance (brake power, specific fuel consumption and thermal efficiency), which were extracted from simulation software, and they act as the most interested data required to calculate the engine performance. The Brake Power $(B P)$ obtains by using

$$
B P=2 \cdot \pi \cdot N T(W)
$$


Where $N \equiv$ the engine speed (revolution per second), and $T \equiv$ engine torque $(\mathrm{Nm}){ }^{[16]}$

The $B s f c$ at different tests conditions calculated in two stages. First the fuel consumptions $(\mathrm{kg} / \mathrm{h})$, divided by the brake power $(k W)$, the $B s f c$ achieves by using ${ }^{[16]}$

$$
B s f c=m_{f}(k g / h) / B P(k W)
$$

The BTE is a ratio, calculated by divided the brake power by the input power. The Input power and BTE obtain by using equations ( 3 and 4 ), respectively. ${ }^{[16]}$

$$
\text { Input power }=m_{f}(\mathrm{~kg} / \mathrm{s}) \times \mathrm{CV}(\mathrm{kJ} / \mathrm{kg})
$$

Where $C V \equiv$ the calorific value of the fuel $(43450$ $(k J / k g)){ }^{[16]}$

$$
\text { BTE }=\frac{\text { Brake Power }}{\text { Input Power }}
$$

The data listed in Table 1 are obtained from the software Diesel - RK, when the specifications of the engine (1VD-FTV) applied in diesel-RK, the Table 1 shows the engine performance in term of $B P, B s f c$, and $B T E$, also

\begin{tabular}{|c|c|c|c|c|c|}
\hline Engine Condition & N (rpm) & BP $(\mathbf{k W})$ & SFC (kg/kWh) & Thermal Efficiency (\%) & $\mathrm{NO}_{\mathrm{x}}(\mathrm{ppm})$ \\
\hline \multirow{8}{*}{ NA } & 750 & 12.5 & 0.4184 & 20.2 & 1232.6 \\
\hline & 1000 & 18.7 & 0.3468 & 24.4 & 1097.9 \\
\hline & 1500 & 31.7 & 0.2778 & 30.5 & 917.4 \\
\hline & 2000 & 43.8 & 0.2613 & 32.4 & 772.6 \\
\hline & 2500 & 54.9 & 0.2566 & 33.0 & 660.1 \\
\hline & 3000 & 63.7 & 0.2605 & 32.5 & 581.5 \\
\hline & 4000 & 72.9 & 0.28195 & 30.0 & 504.9 \\
\hline & 5000 & 74.3 & 0.3211 & 26.4 & 460.3 \\
\hline \multirow{8}{*}{$P R=1.5$} & 750 & 14.1 & 0.3636 & 23.3 & 1422.5 \\
\hline & 1000 & 22.7 & 0.3161 & 26.8 & 1269.5 \\
\hline & 1500 & 39.9 & 0.2659 & 31.9 & 1054.9 \\
\hline & 2000 & 56.2 & 0.2520 & 33.6 & 904.3 \\
\hline & 2500 & 71.2 & 0.2485 & 34.1 & 782.1 \\
\hline & 3000 & 84.2 & 0.2499 & 33.9 & 698.1 \\
\hline & 4000 & 99.9 & 0.2687 & 31.5 & 607.4 \\
\hline & 5000 & 104.7 & 0.3033 & 27.9 & 576.9 \\
\hline \multirow{8}{*}{$P R=2.5$} & 750 & 19.2 & 0.3363 & 25.2 & 1682.3 \\
\hline & 1000 & 22.7 & 0.3006 & 28.2 & 1507.4 \\
\hline & 1500 & 49.9 & 0.2593 & 32.7 & 1240.7 \\
\hline & 2000 & 68.8 & 0.2458 & 34.5 & 1059.8 \\
\hline & 2500 & 86.7 & 0.2417 & 35.0 & 919.4 \\
\hline & 3000 & 102.2 & 0.2437 & 34.8 & 826.7 \\
\hline & 4000 & 117.4 & 0.2632 & 32.2 & 726.6 \\
\hline & 5000 & 126.0 & 0.2954 & 28.7 & 668.3 \\
\hline \multirow{8}{*}{$P R=3.5$} & 750 & 22.0 & 0.3268 & 25.9 & 2411.1 \\
\hline & 1000 & 35.0 & 0.2922 & 29.0 & 2185.4 \\
\hline & 1500 & 61.0 & 0.2512 & 33.7 & 1856.4 \\
\hline & 2000 & 86.0 & 0.2377 & 35.6 & 1608.2 \\
\hline & 2500 & 109.0 & 0.2338 & 36.2 & 1427.1 \\
\hline & 3000 & 130.0 & 0.2365 & 35.8 & 1297.2 \\
\hline & 4000 & 152.0 & 0.2563 & 33.0 & 1169.4 \\
\hline & 5000 & 142.0 & 0.2864 & 29.6 & 1099.2 \\
\hline
\end{tabular}
the nitrogen oxides emissions were considered.

Table 1. Specifications of the engine (1VD-FTV) applied in diesel-RK 


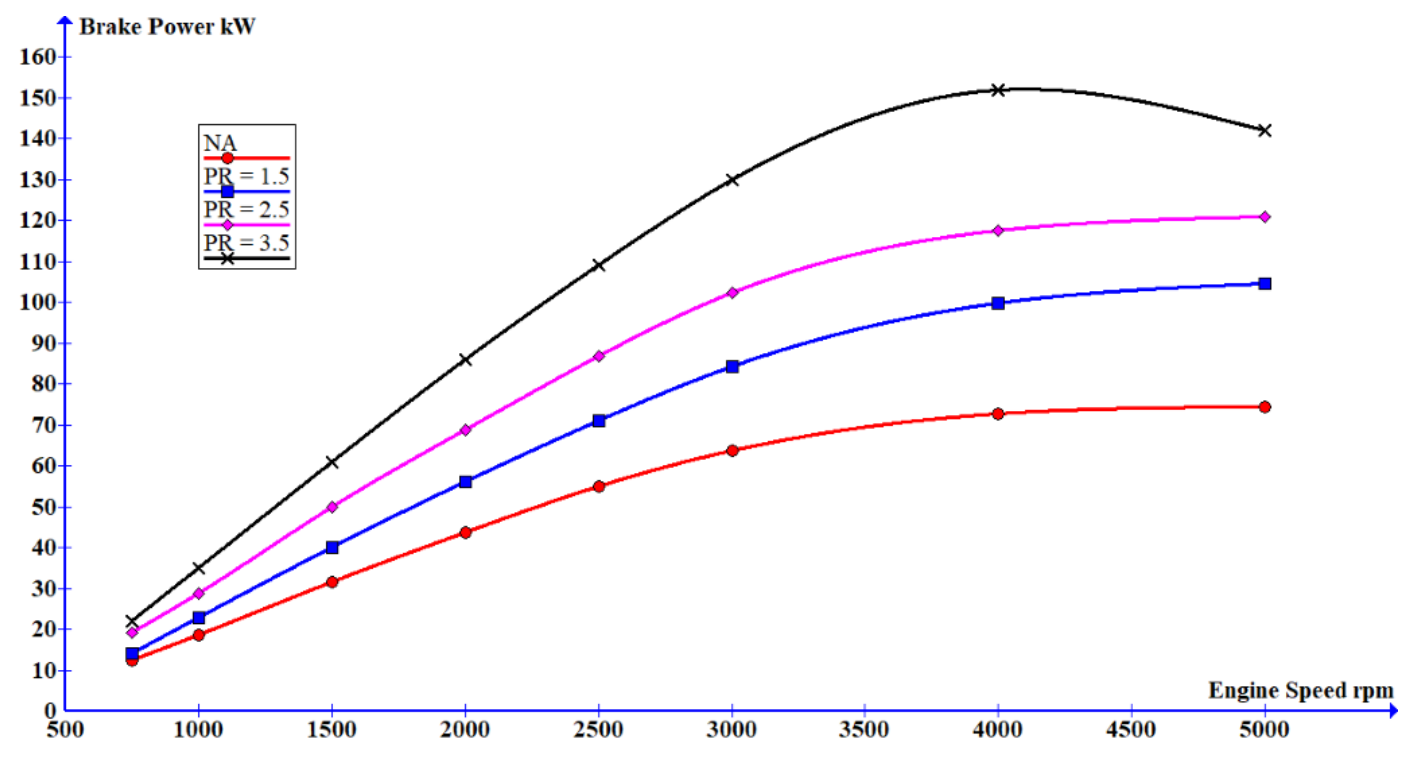

Figure 8. Engine brake power VS engine speeds

\subsection{Brake Power BP $(\mathrm{kW})$}

In this section a brief study will be carried out to investigate the effect of turbocharger pressure ratio to the engine's output power. The experiments were arranged as follows: first the Naturally Aspirated engine was run (NA engine) and secondly at different pressure ratio 1.5, 2.5 and 3.5.

Fig. 8 shows the effect of the different turbocharger pressure ratios on the engine brake power, as the pressure ratio increases the brake power continuously increases. For example, at $2500 \mathrm{rpm}$ and at NA engine the brake power is found to be $54.9 \mathrm{~kW}$, in the presence of pressure ratio $=1.5$ the brake power increased to $71.2 \mathrm{~kW}$, the increment about $29.7 \%$. More increment in the output power can be achieved by increasing the turbocharger pressure ratio to 2.5 , the power is increases to $86.7 \mathrm{~kW}$ the increment about $58 \%$ when compared to the NA engine at the same speed. With the increase of pressure ratio more charged air is available for the combustion process which further tends to increase the combustion efficiency. The brake power increased to $109 \mathrm{~kW}$ when pressure ratio raised to 3.5 and $2500 \mathrm{rpm}$, the increment rate is about $98 \%$ when compared to the NA engine.

Fig. 8 also shows that, when the engine speed increases the brake power will increase continuously, particularly at low engine speeds and up to 4000rpm. The brake power begins to decrease at speed higher than $4000 \mathrm{rpm}$. For example, at setup $\mathrm{PR}=3.5$ and at $3000 \mathrm{rpm}$ the brake power is found to be $130 \mathrm{~kW}$, the power increased to $152 \mathrm{~kW}$ when the engine speed reached to 4000rpm. At high engine speed 5000rpm the power decreased to $142 \mathrm{~kW}$. The reduction percentage is found to $9.2 \%$ when compared to the power gained at 3000rpm. Simply, the engine's volumetric efficiency increases with engine speed, reached the maximum value approximately at $4000 \mathrm{rpm}$ and then falls. Actually, greater volumetric efficiency means extra fresh air is introduced to the cylinder, more oxygen will be available to complete the combustion process. High volumetric efficiency lead to increase the brake power.

The maximum brake power of the engine being studied (1VD-FTV) is equal to $151 \mathrm{~kW}$ and is achieved at 3600 rpm by using single turbocharger according to the engine design and manufacturers. Whereas Fig. 6 shows that the maximum brake power was occurred at $4000 \mathrm{rpm}$ and $\mathrm{PR}=$ 3.5 which is equal $152 \mathrm{~kW}$. The difference is due to that the results obtained by diesel-RK is not completely accurate results and not real, it's a mathematical model results (computer applications). However, simulation software studies the performance of a system without building it. Fig. 6 shows also the maximum brake power that can be obtained in other pressure ratios (1.5 and 2.5) occur at 5000 rpm approximately.

\subsection{Brake Specific Fuel Consumption SFC (kg/kWh)}

In this section a brief study to investigate the influence of turbocharger pressure ratio to the specific fuel consumption. The software is run as follows: first the Naturally Aspirated engine was run (NA engine), second different pressure ratio $1.5,2.5$ and 3.5. SFC is a measure of fuel efficient, is defined as the ratio of fuel consumption per unit time to the useful power generated by the engine. Higher fuel efficiency means the SFC per kilowatt decreased, since the power is developed by least fuel consumption.

Fig. 9 shows the effect of the different turbocharger pressure ratios on the SFC, as the pressure ratio increases the SFC continuously decreases. For example, at 4000rpm and at NA engine the SFC is found to be $0.2819 \mathrm{~kg} / \mathrm{kWh}$, in the presence of pressure ratio $=1.5$ the SFC decreased to $0.2687 \mathrm{~kg} / \mathrm{kWh}$, the reduction about $4.9 \%$. More decrement rate in the SFC can be achieved by increasing 
the turbocharger pressure ratio to 2.5 , where $\mathrm{SFC}$ is decreases to $0.2632 \mathrm{~kg} / \mathrm{kWh}$ the reduction rate about $7.1 \%$ when compared to the NA engine at the same speed. More reduction in specific fuel consumption is achieved when the pressure ratio is increased to 3.5 , therefore at same engine speed the SFC is found to be $0.2563 \mathrm{~kg} / \mathrm{kWh}$, about $10 \%$ reduction rate when compared to NA engine. The highest specific fuel consumption was observed at low and high engine speeds as shown in the Fig. 8. Specific fuel consumption changes with the output of the diesel engine and inverse proportional. From Fig. 8 and 9, the SFC increases with decreases of brake power, the region of the low engine speeds the brake power is minimum, so the SFC is high. At the mid speeds region, the brake power is highest, thus the SFC is minimum, same conduct and manner are seen in the high speeds region. However, when the engine power output increases, the specific fuel consumption decreases sharply for all turbocharger pressure ratios. As an example, for a power output of the setup PR $=1.5$ and $1500 \mathrm{rpm}$. The brake power is equal to $39.93 \mathrm{~kW}$ and the SFC is found to be $0.266 \mathrm{~kg} / \mathrm{kWh}$. At engine speed $=3000 \mathrm{rpm}$, the brake power increased to 84.2 $\mathrm{kW}$, while the SFC decreased to $0.25 \mathrm{~kg} / \mathrm{kWh}$. At high power outputs are found to give lower SFC. At the same setup $\mathrm{PR}=1.5$, the brake power at $5000 \mathrm{rpm}$ is decreased to $104.7 \mathrm{~kW}$, while the SFC increased to $0.30328 \mathrm{~kg} / \mathrm{kWh}$.

\subsection{Brake Thermal Efficiency BTE (\%)}

In general, energy transformation efficiency is the ratio between the output power of the engine and the input power, the input power is in the form of chemical power contained in the fuel. For thermal efficiency, the input $\left(\mathrm{Q}_{\text {in }}\right)$ to the engine is heat or the heat-content of a fuel that is consumed. The desired output is a work $\left(\mathrm{W}_{\text {out }}\right)$ and heat $\left(\mathrm{Q}_{\text {out }}\right)$, the lost heat is due to heat with the exhaust gas, heat dissipated by the engine cooling water and by thermal conduction through the engine body. When expressed the efficiency as a percentage, the thermal efficiency must lay between $0 \%$ and $100 \%$. Due to some losses such as friction, heat loss, and other factors, thermal engines efficiencies are usually much less than $100 \%$.

Fig. 10, shows the impact of the thermal efficiency versus engine speeds at different turbocharger pressure ratios, the Fig.4 shows the best engine setup condition is at $\mathrm{PR}=3.5$. For example, at NA engine and at 3000rpm, the BTE is found to be $32.5 \%$, and at PR $=1.5$, the BTE is increased to $33.9 \%$ while the $\mathrm{BTE}$ at the $\mathrm{PR}=2.5$ is equal to $34.8 \%$. The greatest thermal efficiency is achieved at $\mathrm{PR}=3.5$ setup which is equal $35.8 \%$, the increment rate is about $10 \%$ when compared to NA engine. From the results presented in Fig. 4, it is clear that as the turbocharger pressure ratio increases the thermal efficiency increases. Generally, Turbocharged engine shows the higher BTE than NA diesel engine which is because of the higher charged air and improvement in output power and combustion efficiency.

Fig. 10, also shows the variation of the curve trend for thermal efficiency vs engine speeds for all simulated setups. At low engine speeds (less than 2000rpm) the BTE are increases as the engine speed increases, at same region the brake power are also increases as the engine speed increases. For example, at setup NA engine and 1000rpm, the BTE is found to be $24.4 \%$, and at 2000rpm the BTE increased to $32.4 \%$. The BTE reached the maximum value at $2500 \mathrm{rpm}$ and it equal to $33.0 \%$. At higher engine speeds (greater than 2500rpm) the BTE tends to decreased e.g. at $5000 \mathrm{rpm}$ and NA engine the BTE is found to be $26.4 \%$. The reduction rate of the BTE at higher engine speeds are due to the reduction of the volumetric efficiency of the cylinders, also at high engine speeds, the time required for complete the combustion is reduced.

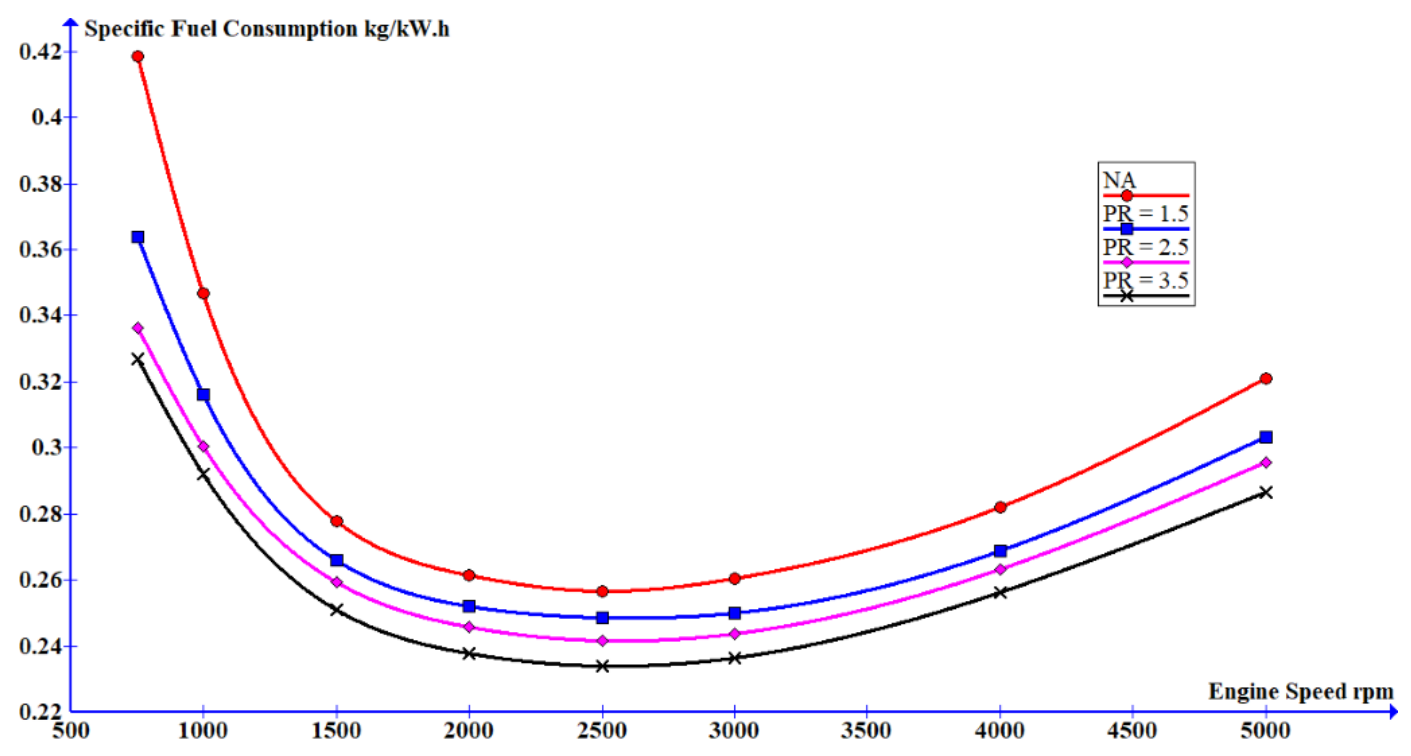

Figure 9. Engine specific fuel consumption VS engine speeds 


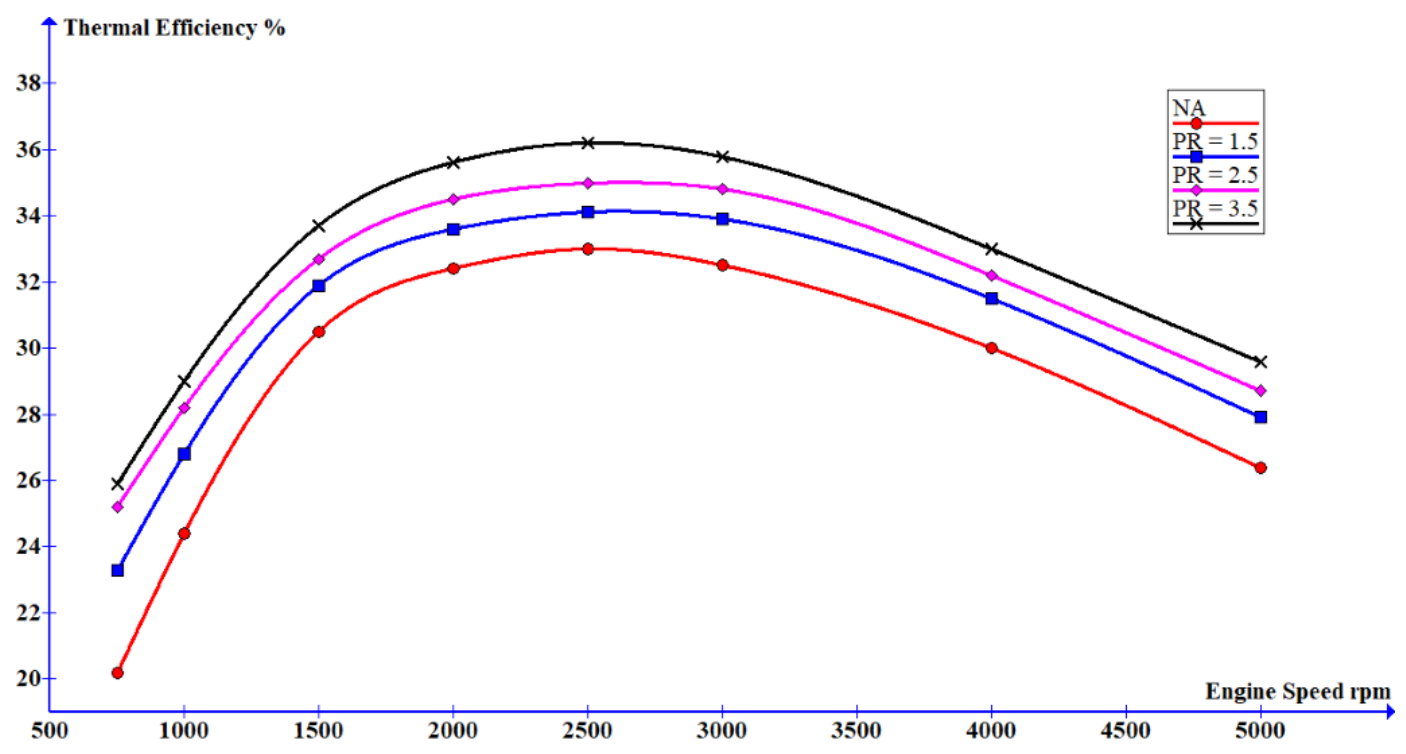

Figure 10. Brake Thermal Efficiency VS engine speeds

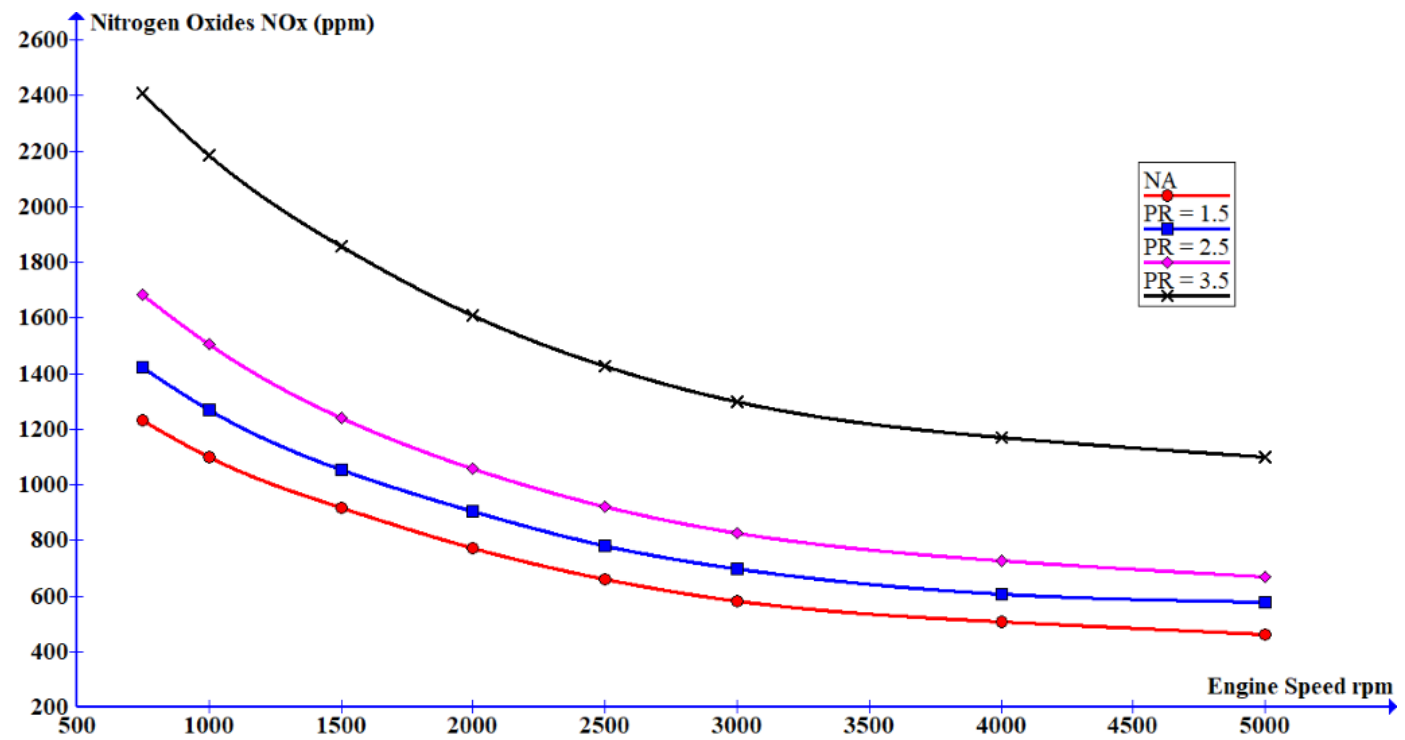

Figure 11. Nitrogen Oxides Emissions VS engine speeds

\subsection{Nitrogen Oxides Emissions (ppm)}

Nitrogen Oxides $\left(\mathrm{NO}_{\mathrm{X}}\right)$ plays an important role in this research. A brief review will be carried out to study the conduct of the nitrogen oxides emissions at different turbocharger pressure ratio. The unit part per million (ppm) is used to express the amount of emitted gas, where ppm is usually used to gauge the small levels of pollutants in the air. The nitrogen oxides formation rate is a function of temperature and the presence of nitrogen and oxygen at that temperature.

Fig. 11, shows the impact of the thermal nitrogen oxides versus engine speed at different turbocharger pressure ratios. At low engine speeds the $\mathrm{NO}_{\mathrm{x}}$ emissions are found to be greater when compared to higher engine speeds. At higher engine speeds there are no enough time for $\mathrm{NO}_{\mathrm{X}}$ formation and also the decreasing of the volumetric efficiency reduces the amount of fresh air (nitrogen and oxygen). For example, at setup PR $=1.5$ and $750 \mathrm{rpm}$ the $\mathrm{NO}_{\mathrm{X}}$ emissions is found to be $1422.5 \mathrm{ppm}$, while at 5000 rpm the $\mathrm{NO}_{\mathrm{x}}$ formation is equal to $576.9 \mathrm{ppm}$, the reduction rate about $41 \%$ due to increases of engine speed from 750 to $5000 \mathrm{rpm}$.

Fig. 11, shows the $\mathrm{NO}_{\mathrm{x}}$ formation is increases as the increase of the turbocharger pressure ratio, both factors presence of excess air and high temperature leads to $\mathrm{NO}_{\mathrm{X}}$ formation. For example, at setup NA engine and $3000 \mathrm{rpm}$ the $\mathrm{NO}_{\mathrm{x}}$ is found to be $581.47 \mathrm{ppm}$, and at the setup $\mathrm{PR}=$ 1.5 and at same engine speed the $\mathrm{NO}_{\mathrm{X}}$ increased to 698.1 ppm, while at $\mathrm{PR}=2.5$ the $\mathrm{NO}_{\mathrm{x}}$ formation increased to $826.7 \mathrm{ppm}$, and at $\mathrm{PR}=3.5$ the $\mathrm{NO}_{\mathrm{X}}$ emissions increased to $1297.2 \mathrm{ppm}$, this increment is just due to the increase of the 
turbocharger pressure ratio.

\section{Conclusions}

The use of turbocharger led to improving engine power, mainly at high pressure ratio due to the great charging air particularly when compared to NA diesel engine over the entire range of engine speeds (750rpm to 5000rpm). For the turbocharged engines, the SFC is improved, thus the SFC is deceased as the turbocharger pressure ratio increased, but SFC is very high at low and higher engine speeds. The NOx emission increased with increase of the pressure ratio when compared to the NA diesel engine, over the entire range of engine speeds (750rpm - 5000rpm). The $\mathrm{NO}_{\mathrm{X}}$ emissions decreased as the engine speed increased.

\section{Nomenclature}

\begin{tabular}{|c|c|c|c|}
\hline BDC & Bottom Dead Center & NO & Nitric Oxide (ppm) \\
\hline BP & Brake Power $(\mathrm{kW})$ & $\mathrm{NO}_{2}$ & $\begin{array}{l}\text { Nitrogen dioxide } \\
(\mathrm{ppm})\end{array}$ \\
\hline BTE & $\begin{array}{l}\text { Brake Thermal } \\
\text { Efficiency (\%) }\end{array}$ & $\mathrm{NO}_{\mathrm{x}}$ & $\begin{array}{l}\text { Nitrogen oxides } \\
\text { (ppm) }\end{array}$ \\
\hline $\mathrm{C}$ & Carbon & mf. & $\begin{array}{l}\text { Fuel Mass Flow Rate } \\
(\mathrm{kg} / \mathrm{s})\end{array}$ \\
\hline $\mathrm{CO}$ & $\begin{array}{l}\text { Carbon Monoxide } \\
(\mathrm{ppm})\end{array}$ & ppm & Parts Per Million \\
\hline CV & $\begin{array}{l}\text { Fuel Calorific Value } \\
\mathrm{MJ} / \mathrm{kg}\end{array}$ & PM & Particular Matters \\
\hline $\mathbf{H}$ & Hydrogen & rpm & Revolution per minute \\
\hline $\mathrm{HC}$ & Hydrocarbon (ppm) & SFC & $\begin{array}{l}\text { Specific Fuel } \\
\text { Consumption } \\
(\mathrm{kg} / \mathrm{kWh})\end{array}$ \\
\hline ICE & $\begin{array}{l}\text { Internal Combustion } \\
\text { Engine }\end{array}$ & $\mathrm{SO}_{2}$ & $\begin{array}{l}\text { Sulphur dioxide } \\
\text { (ppm) }\end{array}$ \\
\hline $\begin{array}{c}\text { MST } \\
\text { U }\end{array}$ & $\begin{array}{l}\text { Moscow State } \\
\text { Technical University }\end{array}$ & TDC & Top Dead Center \\
\hline $\mathbf{N}$ & Engine Speed (rpm) & UHCs & $\begin{array}{l}\text { Unburned } \\
\text { Hydrocarbons (ppm) }\end{array}$ \\
\hline NA & $\begin{array}{l}\text { Natural Aspirated } \\
\text { Engine }\end{array}$ & VGT & $\begin{array}{l}\text { Variable Geometry } \\
\text { Turbocharger }\end{array}$ \\
\hline
\end{tabular}

\section{Acknowledgements}

The authors acknowledge the use of Saudi Aramco diesel Services Organization (SADSO) facilities for the research data utilized in this manuscript. A team of researchers of Mechanical Engineering Department from College of Engineering Unaizah selected graduation project to fulfillment requirements for the degree of B.Sc. in Mechanical Engineering. Also, Researchers would like to thank the Deanship of Scientific Research, Qassim University for funding publication of this project. Finally, a thanks to Professor Andrey Kuleshov (Moscow State Technical University) for allowed us to use the simulation software (diesel-RK).

\section{REFERENCES}

[1] Callahan, T. J. "Reciprocating Engine Technology - Can We Get There From Here?" Southwest Research Institute, Reciprocating Engines Peer Review, Chicago, IL, April 23-24, 2002.

[2] Cox, G., DelVecchio, K, Hays, W., Hiltner, J., Nagaraj, R. and Emmer, C. "Development of a Direct- Injected Natural Gas Engine System for Heavy-Duty Vehicles," Final Report, Phase II, Document no. NREL/SR-540-27501, February 2010.

[3] Dr. Hermann Hiereth, Dr. Peter Prenninger: Charging the Internal Combustion Engine. 2003 ISBN 978-3-211-330333 Springer Wien NewYork

[4] RYTI, M. and MEIER, E., 'On Selecting the Method of Turbo charging Four-stroke Diesel Engines', Brown Boveri Review, 56, No. 1 (2010).

[5] Corky Bell 2007 Maximum Boost: Design, Testing, and Installing Turbocharger System. Bentley Publisher, a division of Robert Bentley Inc.05040302

[6] Duggal, V. Cummins Engine Company Inc., California Advanced Reciprocating Internal Combustion Engines Collaborative, Workshop Proceedings, California Energy Commission, July 10, 2001.

[7] McCormick, M. Waukesha Engine Dresser, Inc., California Advanced Reciprocating Internal Combustion Engines Collaborative, Workshop Proceedings, California Energy Commission Sacramento, CA, July 10, 2001.

[8] Baldwin, D. and Gerber, G. "Advanced Reciprocating Engine Systems," DOE Distributed Energy Peer Review, Arlington, VA, December 13 -15, 2005.

[9] Levendis Y A, Pavalatos I, Abrams R F 2004 Control of diesel soot hydrocarbon and NOx emissions with a particular trap. SAE 940460

[10] Clean Air Technical Center (MD-12). "Nitrogen Oxides (NOx), Why and How They are Controlled," U.S. Environmental Protection Agency, Research Triangle Park, NC, 27711, EPA 456-99-006R, November, 2011.

[11] Campbell, L. M., Stone, D. K. and Shareef, G. S. "Sourcebook: NOx Control Technology Data," U.S. Environmental Protection Agency, Research Triangle Park, NC, Document No. EPA-600/2-91-029, 2001.

[12] Pierpont D A, Montgomery D T, Reitz R D 1995 Reducing particulate and NOx using multiple injections and EGR in a D. I. diesel. SAE 950217

[13] Toyota Repair Manual, Land Cruiser, (Station Wagon), Jul., 2009, Volume 2, Pub. No. RM0813E2

[14] EASTOP and McCONKEY "Applied Thermodynamics for engineering technologist" 1993 ISBN 0-582-09193-4, Prentice Hall Newyork 